\title{
MYXOMATOSIS IN RABBITS IN GREAT BRITAIN
}

$\mathrm{T}$ HE Advisory Committee on Myxomatosis in Rabbits, appointed in 1953 by the Minister of Agriculture and Fisheries and the Secretary of State for Scotland, has now issued a report* which describes the history and nature of this disease, its present distribution in Great Britain, the protection of domesticated rabbits from it, the harm done by rabbits to agriculture and the present recommendations of the Committee with regard to the disease. Myxomatosis was first reported in 1898 from Montevideo. It is a disease caused by a virus which, so far as we know at present, affects rabbits only. Man, domesticated and other animals cannot be infected with it. It is transmitted purely mechanically to rabbits by the fleas, lice, mosquitoes and mites that suck the blood of the rabbit, and these blood-sucking arthropods act just as a pin infected with the virus might. An infected pin may remain capable of transmitting the virus for twelve days, and the mouthparts of a blood-sucking arthropod may remain infective for twenty-five days. The disease has been used successfully in France and Australia for killing large numbers of rabbits, and the benefit to agriculture is already evident. Recently, the disease has spread to Luxembourg, Belgium, Germany, the Netherlands and Spain. During 1936-38 attempts were made to establish the disease among the rabbits on Skokholm Island, off the Pembrokeshire coast, but these failed. In 1953 the disease broke out in Kent and East Sussex, its source being unknown. Attempts were then made to control its spread; but since then, further outbreaks have been confirmed, and at present six of these have been recorded from Kent, two from East Sussex, three from Essex and one from East Suffolk. The localities where these outbreaks have occurred are shown in a map published with the report.

During laboratory experiments on the disease and in natural outbreaks of it, more than 99 per cent of rabbits infected have died; but those that survive develop an immunity, and it is believed in Australia that rabbits there are becoming immune to the disease and that the very high mortality of rabbits that has occurred in that country is now falling considerably. The development of immunity may therefore prevent the use of the disease for killing rabbits in the future.

The report contains a valuable section on the economics of the wild rabbit. Representatives of the rabbit meat, fur, fur felt and fur felt hat trades have estimated that their trades deal each year with 40 million rabbits. The rabbit meat obtained is worth about $£ 7$ million and the skins about $£ 8$ million, $£ 3 \frac{1}{2}$ million of the latter being represented by exports to the United States. Thus wild rabbits provide in Great Britain a total income of about $£ 15$ million a year.

Estimating the cost of the harm that wild rabbits do, the Committee states that nine rabbits eat about as much as two sheep, so that the estimated popula-

* Ministry of Agriculture and Fisheries; Department of Agricuiture Pp. iv +14. (London: H.M.S.O., 1954.) 9d. net. tion of Great Britain of about 60-100 million rabbits, which feed largely on agricultural crops and grass, can deprive domesticated animals of a great deal of food. It has been estimated that rabbits may cause losses of the order of 160,000 tons of wheat a year, which is worth $£ 5.2$ million, and damage to other cereals of the same order, so that the annual loss in this respect is of the order of $£ 15$ million. The most extensive damage is done to grassland, the cost of this being estimated at $£ 21$ million a year. Rabbits also damage kale, swedes and other vegetables and also fruit trees; the harm they do to young trees in forestry plantations makes it necessary to protect these trees at an annual cost of about $£ 2$ million. The Committee considers, in fact, that the damage done by wild rabbits in Britain costs three or four times the income they bring to the trades dealing in them. In Australia it was estimated that the destruction of rabbits resulted in an increase of rural production worth $£ 50$ million during 1952-53 alone.

In order to reach its conclusions the Committee consulted representatives of the animal welfare societies, agriculture, forestry, the trades dealing in rabbits and those concerned with the domestic rabbit. The chairman of the Royal Society for the Prevention of Cruelty to Animals and the chairman of the Committee on Cruelty to Wild Animals are members of the Committee. The animal welfare societies supported the organization of a national campaign to exterminate the wild rabbit by every humane method available as a means of preventing future suffering. The representatives of agriculture and forestry, with the exception of the National Farmers' Union of Scotland, were not generally in favour of deliberate spread of myxomatosis; they felt that, until we know more about the disease, it should be allowed to spread naturally. The representatives of trades dealing in rabbits were concerned about the possible effects of the disease on their trades, and the producers of domestic rabbits sought protection for the domestic rabbit.

The Committee concluded that attempts to control the natural spread of the disease would serve no practical purpose, but that, for humanitarian, legal and other reasons, no attempt should be made to help the spread of the disease or to introduce it where it does not naturally occur. It recommends that the disease should be allowed to run its natural course and that, whenever outbreaks occur, attempts should be made to eliminate survivors of it before they are able to produce numerous offspring immune to the disease. The importation of such live rabbits as the cotton-tail rabbit, which might rapidly become a pest in Great Britain, should be prevented. Special protection should be given to domestic rabbits and information about the best methods of doing this should be distributed. The vaccine which is the only known preventative of the disease should be made available at a reasonable cost to rabbit breeders. The Committee is, meanwhile, watching the disease, and it has started research on it. Further advice will be issued as occasion arises. G. LAPAGE 